\title{
Moderasi Beragama dalam Perspektif Hukum Kasih
}

\author{
Efesus Suratman ${ }^{1}$, Muryati ${ }^{2}$, Gernaida K.R. Pakpahan ${ }^{3}$, \\ Yusak Setianto ${ }^{4}$, Andreas Budi Setyobekti ${ }^{5}$ \\ 1,2,3,4,5 Sekolah Tinggi Teologi Bethel Indonesia Jakarta \\ correspondence: efesus@sttbi.ac.id
}

\begin{abstract}
Conflicts that occur between religious communities make a problem, namely the incompatibility between the concept of the teachings of love from religion and the facts. Fundamentalist attitudes, radicalism, fanaticism, and extremism produced by religion are the triggers for conflict. With this conflict, it can be said that the teachings of love are not implemented properly. The purpose of writing this article is to state the law of love which is implemented in a pluralistic life which is an effort to build a culture of tolerance in religious moderation and is an effort to prevent, resolve horizontal conflicts between religions. The research method used is library research with a descriptive qualitative approach by collecting and digging various literature related to the theological biblical analysis of the law of love. From the analysis of this article, several findings were obtained, namely: first, religion does not function properly, secondly, the teachings of love are not implemented properly, the three concepts of implementing the law of love are the basis for moderating the middle way that can build awareness of tolerance in pluralism.
\end{abstract}

Keywords: conflict; moderation; religion; the law of love; tolerance

\begin{abstract}
Abstrak: Konflik-konflik yang terjadi antar umat beragama menjadikan suatu permasalahan yaitu ketidak sesuaian antara konsep ajaran kasih dari agama dengan fakta yang ada. Sikap fundamentalis, radikalisme, fanatisme dan ekstrimisme yang dihasilkan agama menjadi pemicu terjadinya konflik. Dengan adanya konflik tersebut maka dapat dikatakan bahwa ajaran kasih tidak terimplementasikan dengan baik. Tujuan dari penulisan artikel ini yaitu untuk menyatakan hukum kasih yang diimplementasikan dalam kehidupan majemuk yang menjadi suatu upaya membangun budaya toleransi dalam moderasi agama, dan menjadi suatu upaya pencegah, penyelesai konflik horizontal antar agama. Metode Penelitian yang digunakan adalah penelitian pustaka dengan pendekatan kualitatif deskriptif dengan mengumpulkan dan menggali berbagai literatur yang berkaitan dengan analisis biblis teologis hukum kasih. Dari analisis artikel ini maka didapatkan beberapa penemuan yaitu: pertama, agama tidak berfungsi sebagaimana mestinya, kedua tidak terimplementasinya ajaran kasih dengan baik, ketiga konsep implementasi hukum kasih menjadi dasar dalam moderasi jalan tengah yang dapat membangun kesadaran toleransi dalam kemajemukan.
\end{abstract}

Kata kunci: agama; konfilk; hukum kasih; moderasi; toleransi

\section{Pendahuluan}

Dalam sejarah peradaban manusia terdapat beraneka ragam konflik yang terjadi, terlebih lagi dalam kehidupan manusia yang heterogen baik secara suku, ras, dan agama. Indonesia termasuk negara majemuk dari segi etnis, ras, dan agama; perbedaan seringkali memicu konflik. ${ }^{1}$ Huntington mengatakan konflik dapat terjadi dalam budaya yang dipilah-pilah sehingga

${ }^{1}$ Andreas Budi Setyobekti, Susanna Kathryn, and Suwondho Sumen, "Implementasi Nilai-Nilai Bhineka Tunggal Ika Dalam Membingkai Keberagaman Pejabat Gereja Bethel Indonesia Di DKI Jakarta," SOTIRIA (Jurnal Theologia dan Pendidikan Agama Kristen) 4, no. 1 (2021): 1-10. 
konflik yang dihadapi umat manusia menjadi beragam. Konflik memberikan kesengsaraan bagi kedua belah pihak yang menjalaninya. Selain itu, konflik menimbulkan kecemasan bagi masyarakat. ${ }^{2}$

Dalam tatanan kehidupan bermasyarakat, secara khusus di Indonesia ada nilai-nilai atau norman-norma yang dipegang oleh masing-masing individu dalam bentuk agama. Nilai yang dikandung dalam system agama memiliki arti yang khusus dalam kehidupan individu serta dipertahankan sebagai bentuk ciri khas, Sistem tersebut terbentuk dari proses sosialisasi, belajar, pengaruh dari eksternal ataupun internal latar belakang pendidikan dan hal lainnya. Selanjutnya itu akan menjadi identitas dari orang tersebut yang mempengaruhi bagaimana orang tersebut bersikap, bagaimana orang tersebut berpenampilan maupun bagaimana orang tersebut turut berpartisipasi dalam suatu kegiatan tertentu.

Dalam kehidupan bermasyarakat baik secara solidaritas ataupun konsensus Agama dapat menjadikan individu memiliki nilai dalam bentuk keabsahan dan pembenaran, sehingga sistem yang mempengaruhi kehidupan individu tersebut menjadi pendorong supaya individu dapat mengatur pola tingkah laku, pola pikir, dan pola bersikap. Nilai-nilai kehidupan terkandung dalam agama untuk kehidupan manusia, dengan nilai-nilai tersebut maka manusia memiliki acuan atau panduan dalam menjalani hidup. Menurut Elizabeth K. Nottingham, agama memiliki tujuan yaitu mengharmoniskan jiwa mereka dengan alam semesta, mengagungkan Tuhan dan melaksanakan kehendak-nya secara lebih sempurna. Agama mengenalkan pada hal yang buruk dan baik. Agama menjadi penyeimbang antara fisik dan jiwa manusia. ${ }^{3}$

Setiap agama memiliki nilai utama yang beralaskan cinta kasih kepada Tuhan dan kepada sesama manusia. Jika melihat definisi agama dan juga ajaran kasih maka sangat tidaklah tepat menjadikan agama sebagai suatu alasan atau isu terjadinya pertikaian atau konflik.4 Mengacu kepada penelitian sebelumnya yang digunakan sebagai landasan untuk menyatakan kebaharuan dalam penelitian ini, penelitian terdahulu yang dilakukan oleh Frits Octavianus Tatilu yang membahas mengenai Hukum Kasih: Landasan Bersama AgamaAgama, ${ }^{5}$ Selanjutnya penelitian dari Rencan Carisma Marbun, dengan pembahasan Kasih Dan Kuasa Ditinjau Dari Perspektif Etika Kristen, ${ }^{6}$ Mihai Stelian penelitian dengan judul Theorising love in sociological thought: Classical contributions to a sociology of love, ${ }^{7}$ hasil penelitiannya yaitu menunjukkan bagaimana konseptualisasi Kasih tertanam dalam konstruksi teoretis yang lebih luas yang disiapkan untuk menjelaskan proses modernisasi. Kasih sebagai kekuatan pengikat yang fungsi sosialnya adalah untuk mengintegrasikan perbedaan-perbedaan. Lisalalu oleh Afsari Putri A. dengan judul Relevansi Hukum Cinta Kasih untuk Hidup Beragama di Indonesia Sekarang ini.8 Penelitian lainnya yaitu dari Desy Handayani dengan penelitian

\footnotetext{
${ }^{2}$ Gernaida K R Pakpahan, "Analysis of Worring among Lecturers of Indonesian Bethel Theology on Covid19," Medico-Legal Update 20, no. 4 (2020): 1330-1337.

${ }^{3}$ Ramli, "Agama Dan Kehidupan Manusia," Jurnal Pendidikan dan Ilmu-ilmu Sosial 7Jurnal Pe, no. 2 (2015): 138-144.

${ }^{4}$ Frits Octavianus Tatilu, "Hukum Kasih: Landasan Bersama Agama-Agama," Societas Dei: Jurnal Agama dan Masyarakat 4, no. 2 (2018): 8.

${ }^{5}$ Tatilu, "Hukum Kasih: Landasan Bersama Agama-Agama."

${ }^{6}$ Rencan Carisma Marbun, "Kasih Dan Kuasa Ditinjau Dari Perspektif Etika Kristen," Jurnal Teologi Cultivation 3, no. 1 (2019): 88-97.

${ }^{7}$ Mihai Stelian Rusu, "Theorising Love in Sociological Thought: Classical Contributions to a Sociology of Love," Journal of Classical Sociology 18, no. 1 (2017): 3-20, https://journals.sagepub.com/doi/10.1177/1468795X17700645.

${ }^{8}$ Lisa Afsari Putri Almasari, "Relevansi Hukum Cinta Kasih Untuk Hidup Beragama Di Indonesia Sekarang Ini," 2019.
} 
Implementasi Hukum Allah dalam Matius 22:34-40 bagi Pengembangan Komunitas Kristen. ${ }^{9}$ Moderasi agama terhadap radikalisme yang ada di Indonesia berlatar belakang karena persoalan domestik dan konstelasi politik, sehingga agama Kristen dengan dasar teks Alkitab perlu mengajarkan kasih dan sikap pluralis. ${ }^{10}$ Moderasi beragama merupakan sikap penerimaan pihak lain yang bersikap toleran, menaruh hormat dan tidak memaksankan kehendak dengan cara yang keras. ${ }^{11}$ Maka dengan demikian peneliti dalam artikel ini menyatakan kebaharuan yang berbeda dengan penelitian yang sebelumnya perbedaan itu terletak di kajian dan fokus penelitiannya. Peneliti dalam artikel ini berupaya membahas moderasi beragama dalam perspektif Hukum Kasih, maka implementasi hukum kasih tersebut berfungsi sebagai tindakan prefentif atau pencegahan dari banyak konflik yang disebabkan salah satu faktor, yaitu agama.

Perlunya menerapkan moderasi agama karena berkaitan dengan interaksi social yang selalu ada perbedaan yang terjadi antar manusia. Jika perbedaan ditanggapi dengan salah maka akan berujung konflik, di mana akan ada yang dijatuhkan dari salah satu pihak. Kata konflik itu sendiri berasal dari kata kerja bahasa Latin yaitu configere yang memiliki pengertian saling memukul. Membahas mengenai konflik tidak dapat dipisahkan dari ilmu Sosiologi. Secara sosiologis, konflik memliki pengertian suatu proses sosial antar dua orang atau lebih (antar kelompok) yang berusaha meyingkirkan atau menghancurkan salah kelompok atau pihak lainnya. ${ }^{12}$

Kerangka mayoritas dan minoritas dimanfaatkan untuk menimbulkan ketidakadilan dan berbagai permasalahan lainnya, dimana mayoritas mendominasi minoritas baik sekala secara nasional ataupun daerah. Isu mayoritas dan minoritas menjadu isu yang sexy untuk dimaiankan, beberapa contoh kasus di mana pertikaian antar suku seperti yang terjadi di Kalimantan, Ambon dan Papua merupakan trigger isu lain yang sering dimunculkan juga. ${ }^{13}$ Dari isu mayoritas dan minoritas maka akan merambah kepada isu agama dan isu ini adalah isu yang sangat "laris" digunakan dalam terjadinya konflik. Terjadi polarisasi karena perbedaan yang ada karena tidak disikapi dengan benar. Beberapa contoh konflik yang terjadi sebagai berikut: berita Online Kompas yang mengutip informasi dari Yayasan Denny JA mencatat selama 14 tahun setelah masa reformasi setidaknya ada 2.398 kasus kekerasan dan diskriminasi yang terjadi di Indonesia. Dari jumlah kasus tersebut sebanyak 65 persen berlatar belakang agama, beberapa konflik yang ada di Indonesia yang menyebabkan kerugian baik secara moril ataupun materil, konflik-konflik itu antara lain:

\begin{tabular}{|c|l|c|}
\hline NO & TAHUN & \multicolumn{1}{c|}{ KONFLIK } \\
\hline 1 & $\begin{array}{l}\text { Tahun } 1999 \text { sampai } \\
2003\end{array}$ & Konflik Ambon yang menelan korban sebanyak 10.000 orang \\
\hline 2 & Tahun 2001 & $\begin{array}{l}\text { Konflik sampit, konflik yang terjadi di Kalimantan Tengah. Bentrokan } \\
\text { antara warga Suku Dayak dan Suku Madura pada 18 Februari 2001. }\end{array}$ \\
\hline
\end{tabular}

\footnotetext{
${ }^{9}$ Dessy Handayani, "Implementasi Hukum Allah Dalam Matius 22:34-40 Bagi Pengembangan Komunitas Kristen" 11 no 1, no. 1 (2020): 49-60, https://e-journal.stapin.ac.id/index.php/pneumatikos/article/view/24.

${ }^{10}$ Priyantoro Widodo and Karnawati Karnawati, "Moderasi Agama Dan Pemahaman Radikalisme Di Indonesia," PASCA: Jurnal Teologi dan Pendidikan Agama Kristen 15, no. 2 (2019): 17.

${ }^{11}$ Agus Akhmadi, "MODERASI BERAGAMA DALAM KERAGAMAN INDONESIA RELIGIOUS MODERATION IN INDONESIA'S DIVERSITY," Jurnal Diklat Keagamaan 13, no. 2 (2019): 14, https://bdksurabaya.ejournal.id/bdksurabaya/article/download/82/45.

${ }^{12}$ M. Fahim, Sosiologi Agagama Kosenp, Metode Riset, Dan Konflik Sosial (Malang: Madani, 2016), 51.

${ }^{13}$ Adon Nasrullah, Agama Dan Konflik Sosial Studi Kerukunan Umat Beragama, Radikalisme Dan Konflik Antarumat Beragama (Bandung: CV.Pustaka Setia, 2015), 147.
} 


\begin{tabular}{|l|l|l|}
\hline & & $\begin{array}{l}\text { Menurut, Yayasan Denny JA, tercatat ada sekitar 469 orang } \\
\text { meninggal dalam konflik tersebut. Sebanyak 108.000 orang harus } \\
\text { mengungsi. }\end{array}$ \\
\hline 3 & $13-15$ Mei 1998. & $\begin{array}{l}\text { Kerusuhan, kerusuhan yang berlangsung di Jakarta tersebut } \\
\text { setidaknya banyak korban yang meninggal, pemerkosaan dan } \\
\text { 70.000 orang harus mengungsi. }\end{array}$ \\
\hline 4 & $2016-2017$. & Konflik Ahmadiyah \\
\hline 5 & Tahun 2012 & $\begin{array}{l}\text { Konflik Lampung, terjadi pada tahun } 2012 \text { yang menyebabkan } 14 \\
\text { orang tewas dan ribuan orang mengungsi, }\end{array}$ \\
\hline 6 & Tahun 2001 & $\begin{array}{l}\text { Konflik Poso, peristiwa ini terjadi pada tahuh } 1998 \text { sampai tahun } \\
\text { 2001, konflik antara Islam dan Kristen. }{ }^{14}\end{array}$ \\
\hline 7 & 2015 & Pembakaran Gereja HKI Suka Makmur di Aceh Singil pada $2015,{ }^{15}$ \\
\hline 8 & 20 Juli 2016 & $\begin{array}{l}11 \text { wihara dan 2 yayasan dirusak oleh warga mengamuk di } \\
\text { Tanjungbalai, Sumatera Utara. }\end{array}$ \\
\hline & $2014-2019$ & 32 Gereja ditutup dari 2014-2019 \\
\hline
\end{tabular}

Tingginya konflik yang berkaitan dengan berbagai isu terjadi di Indonesia pada masa setelah reformasi. Didukung oleh data beberapa lembaga yang menunjukkan tingginya angka kekerasan di Indonesia pasca reformasi. Pertahun 2011 yang muncul di laporan paling mutakhir Center for Religious \& Cross-cultural Studies atau CRCS UGM yang tak berbeda secara signifikan dari beberapa tahun sebelumnya. Hal ini membuktikan kemunduran yang semakin nyata. ${ }^{17}$ Konflik horizontal terjadi karena masing-masing kelompok memiliki tujuan dasar yaitu penerimaan, pengakuan dan bahkan penghargaan dari kelompok yang sedang berseberangan. ${ }^{18}$ Menurut Chaider S. Bamualim konflik horizontal merupakan konflik sosial dan komunal karena konflik ini bersifat massif dan melibatkan banyak orang, dan peristiwanya berlangsung dalam jangka waktu yang panjang. ${ }^{19}$ Hampir semua masalah dunia, terutama terorisme, overpopulasi, kemiskinan, seksual kejahatan dan perlakuan tidak adil terhadap wanita dapat ditelusuri kembali ke agama. ${ }^{20}$

Pertikaian atau konflik yang terjadi di dalam setiap kasih nir-duniawi religious menurut Max Webber memiliki ukuran dan alasan yang sama yaitu adanya tegangan dengan ruang prilaku politik. Menurut Weber tegangan tersebut terjadi karena agama melangkah menuju keapapun yang menyerupai status yang setara dengan ruang asosiasi politik.21 Semakin keimanan berusaha mengorganisasikan diri sebagai kekuatan independen maka akan semakin kuat nuansa otoritas-otoritas politiknya. Semakin suatu agama mensyaratkan aspek-aspek agama komunal maka semakin situasi politis bekerja sama meminjamkan transfigurasi religiusnya ke etika pihak-pihak yang dikuasai.22

\footnotetext{
${ }^{14}$ Kompas.com, "Kasus Kekerasan Yang Dipicu Masalah Keberagaman Di Indonesia?" (Jakarta, 2020).

${ }^{15}$ BBC Indonesia, "No Title," n.d., https://www.bbc.com/indonesia/indonesia-50471436.

${ }^{16}$ Tirto.id, "Ada 32 Gereja Ditutup Sepanjang 5 Tahun, Jokowi Ke Mana?," 2019, https://tirto.id/ada-32gereja-ditutup-sepanjang-5-tahun-jokowi-ke-mana-dhkD.

${ }^{17}$ Andik Muqoyyidin, "POTRET KONFLI K BERNUANSA AGAMA DI INDONESIA Signifikansi Model
} Resolusi Berbasis Teologi Transformatif" (n.d.): 5,

https://www.researchgate.net/profile/Andik_Muqoyyidin/publication/322050634_links/5a40e149a6fdcce1970ffe53/P OTRET-KONFLIK-BERNUANSA-AGAMA-DI-INDONESIA- Signifikansi-Model-Resolusi-Berbasis-TeologiTransformatif.

${ }^{18}$ Andi Muh. Darlis, Konflik Komunal: Studi Dan Rekonsiliasi Konflik Poso (Yogyakarta: Buku Litera, 2017),

7.

${ }^{19}$ Chaider S. Bamualim (Eds.), Communal Conflicts in Contemporary Indonesia (Jakarta: UIN, KAS, 2015).

${ }^{20}$ EBA, HOW ALL RELIGIONS ARE FALSE AND HARMFUL: A Scientific Explanation of 7 Major Religions (Judaism, Christianity, Islam, Hinduism, Buddhism, Jainism \& Sikhism) (EBA, 2016), 8.

${ }^{21}$ Max Weber, Sosiologi Agama Literatur Utama Dalam Studi Relasi Sosiologi Dan Agama (Yogyakarta: IRCiSoD, 2019), 429.

${ }^{22}$ Weber, Sosiologi Agama Literatur Utama Dalam Studi Relasi Sosiologi Dan Agama. 
Paham yang dimiliki oleh setiap individu ataupun suatu kelompok agama yang dibalut dengan fanatisme berlebihan dapat menyebabkan benturan, sekup yang lebih sempit adalah mengacu kepada individunya sendiri.23 Kepentingan yang utama ini menurut peneliti tidak bisa dilepaskan dari kepentingan politik sehingga terjadi benturan. Padahal seharusnya melalui agama dapat menjalankan peran dalam membangun kedamaian bukan konflik. ${ }^{24}$

Dari penjelasan diatas maka dapat dimunculkan tesis bahwa agama sangat diyakini sebagai inti dan sentral kehidupan manusia, agama menjadi inti kebudayaan yang menjadi acuan kehidupan manusia, agama dipandang sebagai kekuatan integrative yang menyatukan secara structural-kultural unsur-unsur penyusun mayarakat, agama menyatukan anekaragam pengnutnya yang memiliki latar belakang yang berbeda, memberikan kedamaian dan menyatakan kasih. ${ }^{25}$ Namun pada faktanya persoalan konflik yang terjadi seringkali terjadi karena factor agama, ada ketidak sesuaian dengan ajaran kassih dan implementasinya dalam kehidupan masyarakat yang majemuk. Hukum kasih atau ajaran kasih yang diajarkan oleh agama dan teori-teori tentang ajaran kasih tidak sesuai dengan kenyataan yang terjadi. Tujuan dari penulisan artikel ini yaitu untuk menyatakan hukum kasih yang diimplementasikan dalam kehidupan majemuk yang menjadi suatu upaya membangun budaya toleransi dalam moderasi agama, dan menjadi suatu upaya pencegah, penyelesai konflik horizontal antar agama.

\section{Metode Penelitian}

Berdasarkan latar belakang masalah yang dipaparkan sebelumnya, maka peneliti menggunakan metodologi penelitian yang digunakan adalah kualitatif. Di mana penelitian dengan tujuan untuk memahami fenomena tentang apa yang dialami oleh subyek penelitian misalnya prilaku, persepsi, motivasi, tindakan dalam lain-lain secara holistik, dan dengan cara deskriptif dalam bentuk kata-kata dan bahasa, pada suatu konteks khusus yang alamiah dan dengan memanfaatakan bebagai metode alamiah. Pendekatan yang dimiliki oleh penelitian kualitatif yaitu pendekatan analisa yang mendalam (indepth analisys) dengan penalaran induktif (penalaran khusus ke umum). ${ }^{26}$

\section{Hasil dan Pembahasan}

\section{Agama}

Agama merupakan system yang mengatur tata keimanan kepercacyaan dan peribadatan kepada Tuhan yang Mahakuasa serta tata kaidah yang berhubungan dengan pergaulan antara manusia serta antara manusia dengan lingkungannya. Oleh karena itu di dalam agama terdapat larangan dan perintah yang harus dilakukan yang terangkum dalam suatu komunitas dan anggotanya harus mematuhinya. 27 Suatu masyarakat akan dipengaruhi pola kehidupannya oleh agama, bahkan untuk menangani masalah yang tidak dapat dipecahkan oleh teknologi dan teknik organisasi yang tidak diketahuinya agama menjadu solusi terhadap masalah itu. ${ }^{28}$

\footnotetext{
${ }^{23}$ Susilo Wibisono \& Muhammad Taufik, "ORIENTASI KEBERAGAMAAN EKSTRINSIK DAN FUNDAMENTALISME AGAMA PADA MAHASISWA MUSLIM: ANALISIS DENGAN MODEL RASCH," Jurnal Psikologi Sosial 15, no. 1 (2017): 1-11, http://journal.ui.ac.id/index.php/jps/article/viewFile/jps.2017.1/3775.

${ }^{24}$ Achmad Djatmiko, Agama Dan Kajian Hubungan Internasional (Yogyakarta: ANDI, 2019), 52.

${ }^{25}$ H.M. Ridwan Lubis, Sosiologi Agama Memahami Perkembangan Agama Dalam Interaksi Sosial (Jakarta: Prenadamedia Group, 2015), v.

${ }^{26}$ Lexy J. Moleong, Metodologi Penelitian Kualitatif (Bandung: Remaja Rosdakarya, 2007), 6.

${ }^{27}$ Andreas A. Yewangoe, Tidak Ada Negara Agama - Satu Nusa, Satu Bangsa (Jakarta: BPK Gunung Mulia, 2009), 30.

${ }^{28}$ Rizal Mubit, "Peran Agama Dalam Multikulturalisme Masyarakat Indonesia," Epistemé: Jurnal Pengembangan Ilmu Keislaman 11, no. 1 (2016): 14.
} 
Pengaruh yang diberikan agama sangat kuat dan juga dapat dikatakan menjadi bagian jati diri manusia.

Realitas social yang tidak dapat dipungkiri atas peran penting dari agama yaitu sebagai modal sosial yang pada satu sisi mendorong transformasi sosio-budaya dan pada sisi lain, mengawetkan distingsi-distingsi sosial dan/atau identifikasi yang potensial menciptakan segregasi sosial bahkan konflik kekerasan. ${ }^{29}$ Dikatakan demikian karena agama menjadi kotak-kotak atau pembatas antara masyarakat yang majemuk yang tidak jarang menyebabkan konflik karena perbedaan.

Jika melihat kepada definisi agama yang berasal dari Bahasa Sansekerta (Sanskrit) atau Pali,30 "agama" dalam bentuk jamaknya yaitu agamas, maka dapat diketahui bahwa dalam agama terdapat kumpulan dogma yang didalamnya berisi tentang tatacara dan aturan-aturan mengenai hubungan manusia dengan Tuhan, atau keyakinan-keyakinan manusia kepada suatu hal yang sifatnya supranatural. 31 Melalui hal tersebut maka dalam keyakinan yang tersistem manusia akan menginterpretasikan pengalaman terhadap dunia gaib. ${ }^{32}$ Dari agama yang menjadi sumber inspirasi atas tradisi dan kebudayaan akan menjadi tempat pengamalan nilai-nilai dari agama itu sendiri. ${ }^{33}$ Menjalankan fungsi agama yang tidak dapat dilepaskan dari realitas kehidupan masyarakat yang akan membentuk identitas dan pendewasaan diri. ${ }^{34}$

\section{Pemaknaan Kasih dari Perspektif Agama}

Kasih merupakan suatu kesadaran dan sifat bawaan manusia dan memang sudah seharusnya tidak dapat dilepaskan dari kehidupan manusia. Manusia adalah gambar Allah, sebagaimana natur Allah penuh dengan belas kasihan dan Dia adalah kasih. ${ }^{35}$ Sehingga setiap agama memiliki ajaran kasih masing-masing seperti halnya: ajaran agama Islam dalam konsep ajaran Akhlaqul Karimah yaitu ahlak atau budi perkerti yang luhur dan mulia (baik ahklak kepada Tuhan atau kepada sesama manusia. Ajaran ahlak itu diterapkan dalam ajaran kasih yang dinyatakan dalam ajaran hablum minallah dan hablum minannas dalam menjalani kehidupan sebagai Muslim harus memperhatikan dua hal, yakni hubungan dengan Allah SWT dan hubungan dengan sesama manusia ${ }^{36}$.

Ajaran kasih dalam agama Hindu ada kaitannya dengan keyakinan Karma dan Samsara. Konsep ajaran kasih terdapat pada ajaran Tat Twam Asi yang intinya yaitu cinta kasih merupakan satu kesatuan, aku adalah kamu, dan kemudian maknanya itu dikembangkan lagi menjadi engkau adalah dia, dia adalah mereka dan seterusnya, sebagaimana yang terdapat dalam kitab Chandogya Upanisad VI. 14. 1.37

\footnotetext{
${ }^{29}$ Steve Gerardo Christoffel Gaspersz, "Relasi Muslim-Kristen Di Pulau Ambon :," no. 01 (2021): 16, https://www.nusantarainstitute.com/wp-content/uploads/2021/01/NI-Working-Paper-01-21-Steve-Gasperz.pdf.

${ }^{30}$ Achmad Djatmiko, Agama Dan Kajian Hubungan Internasional.

${ }^{31}$ Sumanto Al Qurtuby, "Antara Agama, Manusia, Dan Tuhan," Nusantara Institute (2020): 7, https://www.nusantarainstitute.com/antara-agama-manusia-dan-tuhan/.

32 Petrik Matanasi, "Agama-Agama Nusantara Yang Dipinggirkan," Nusantara Institute (2020): 6, https://www.nusantarainstitute.com/agama-agama-nusantara-yang-dipinggirkan.

${ }^{33}$ Zastrouw Al-Ngatawi, "Agama Tidak Bisa Dilepaskan Dari Tradisi Dan Budaya," Nusantara Institute (2020), https://www.nusantarainstitute.com/agama-tidak-bisa-dilepaskan-dari-tradisi-dan-budaya/.

${ }^{34}$ Fahim, Sosiologi Agagama Kosenp, Metode Riset, Dan Konflik Sosial.

${ }^{35}$ Muryati Muryati, Gernaida Pakpahan, and Junifrius Gultom, "Sastra Satire Kitab Yunus : Analisis Naratif Prolog Dan Epilog Kitab Yunus" 3, no. 1 (2020): 106-118.

${ }^{36}$ Yahya Komarudin, "KORELASI ANTARA PENGETAHUAN AGAMA ISLAM DAN" 1, no. 1 (2020): 3.

${ }^{37}$ AAG. Raka Putra, "Cinta Kasih Dalam Perspektif Hindu," Media Hindu (Bekasi, 2016), https://www.mediahindu.org/2016/08/23/cinta-kasih-dalam-perspektif-hindu/\#: :text=Adapun yang mendasari cinta kasih, dalam kitab Chandogya Upanisad VI.
} 
Dalam ajaran agama Buddha ajaran kasih terdapat dalam prinsip Metta Paramita ajaran tentang cinta kasih tertuang yaitu sifat-sifat luhur cinta kasih tanpa keinginan untuk memiliki, yang ditujukan kepada semua makhluk tanpa membeda-bedakan ras, bangsa dan agama. Ajaran mengenai Metta atau kasih merupakan ajaran rasa persaudaraan, persahabatan, pengorbanan, yang mendorong kemauan baik, memandang makhluk lain sama dengan dirinya sendiri supaya teerjadi keharmonisan dalam kehidupan. ${ }^{38}$ Mettā itu salah satu kata yang terdapat di kumpulan Sutta-Sutta (Nikāya Pāḷi) yang diterjemahkan sebagai cinta kasih ini berbeda dengan cinta kasih. Mettā menggambarkan cinta kasih dan belas kasih yang dipancarkan secara universal.

Ajaran kasih dalam Kekristenan disebut dengan Hukum Kasih. Esensi aturan ini tidak hanya sekedar mencakup esensi empatik dan moralitas saja namun lebih dari pada itu karena esensinya bersifat sangat teologis. Dalam aturan ini ada karakter Tuhan yang membimbing bagaimana manusia harus berinteraksi dan berhubungan dengan sesama manusia. John Wesley menyatakan keselamatan yang orang percaya terima akan mempengaruhi orang dalam kasih, kasih tersebut menjadi suatu jembatan yang digunakan untuk menjangkau orang untuk merasakan keselamatan yang sudah Tuhan berikan. Melalui kasih yang dilakukan maka orang lain yang belum percaya dapat mengenal keselamatan itu. ${ }^{39}$

Dasar konsep Hukum Kasih dalam agama Kristen yaitu Alkitab perjanjian Lama dan Perjanjian Baru. Konsep kasih yang dimiliki oleh Kekristenan yaitu dimulai dari kasih Allah kepada manusia, kasih manusia kepada Allah, dan juga kasih manusia kepada manusia. Kasih Allah kepada manusia dalam Perjnajian Lama terkonsep dalam kata khesed yang menunjukan kebaikan, kemurahan Allah yang tanpa syarat, kasih setia yang memiliki keterkaitan dengan perjanjian. ${ }^{40}$ Kata ini memiliki keterkaitan yang sangat erat dengan perjanjian antara Allah dengan bangsa Israel, Allah menyatakan kasih-Nya di dalam perjanjian.

Kasih Allah kepada manusia dalam Perjanjian Baru, dinyatakan dalam bentuk keselamatan yang merupakan rencana Allah. Keselamatan tersebut merupakan bukti nyata komitmen kasih Allah dalam perjanjian-Nya. Yesus merupakan bukti kasih Allah dan merupakan satusatunya jalan untuk keselamatan tersebut (bdg. Yoh. 14:6). Satu-satunya cara Allah untuk memperbaiki relasi antara Allah dengan manusia hanya melalui pengorbanan Yesus di kayu salib. Tidak ada satu namapun di bawah kolong langit yang memberikan keselamatan selain nama Yesus (bdg. Kis. 4:12). Manusia mengalami pendamaian dengan Allah karena kasih-Nya melalui Yesus Kristus. Kasih Allah melalui Yesus untuk manusia adalah kasih tanpa syarat yang merupakan inisiatifnya Allah. Tindakan kesalahan manusia tidak mempengaruhi atau membatalkan kasih Allah. Kasih Allah kepada manusia sangat terlihat sekali dalam konsep penebusanNya.

Kasih manusia kepada Allah (Mat. 22:37-38) baik itu dalam Perjanjian Lama dan Baru merupakan suatu respons dari manusia atas kasih Allah yang sudah diberikan keapda manusia. Dengan manusia menaati ketetapan dan hukum-hukum Allah maka manusia sedang menjaga relasi dengan-Nya, selain daripada itu juga manusia mengasihi Allah karena kesadaran akan status kehidupan manusia adalah umat kepunyaan Allah, harta kesayangan, jantung hati, biji mata Allah. Oleh karena itu manusia perlu mengasihi Allah dengan segala hidupnya.

\footnotetext{
${ }^{38}$ EBA, HOW ALL RELIGIONS ARE FALSE AND HARMFUL: A Scientific Explanation of 7 Major Religions (Judaism, Christianity, Islam, Hinduism, Buddhism, Jainism \& Sikhism).

${ }^{39}$ Stephen Prothero, "RELIGIOUS LITERACY What Every American Needs to Know-and Doesn't," Journal of Chemical Information and Modeling 53, no. 9 (2013): 35.

${ }^{40}$ J.D Doglas, Ensiklopedi Alkitab Masa Kini Jilid 1 A-L (Jakarta: YKBK, 2018), 524.
} 
Kasih kepada sesama manusia merupakan suatu pembuktian bahwa manusia mengasihi Allah sehingga manusia harus mengasihi sesamanya manusia. Standar untuk mengasihi sesama adalah bagaimana mengasihi diri sendiri seperti yang tertulis dalam Matius 22:39. Seseorang ingin memiliki hidup yang berarti, merasakan kebahagiaan, kenyamanan ataupun keamanan, itu semua merupakan bentuk mengasihi diri sendiri. Seperti halnya seperti yang dikatakan oleh Blaise Pascal, semua orang mencari kebahagiaan tanpa terkecuali. ${ }^{41}$

Dari penjelasn-penjelasan diatas maka idealnya yaitu agama seharusnya menjadi tempat untuk menghasilkan kedamaian, namun berbanding terbalik dengan fakta yang ada, agama menjadi sumber konflik horizontal. Agama yang tidak lagi menjalankan sebagaimana fungsinya dan tidak lagi menyuarakan ajaran dan juga moral yang otentik dalam masyarakat yang majemuk. Ajaran kasih dari tiap-tiap agama tidak lagi terimplementasi dengan baik karena berbagai macam faktor seperti: ketertutupan (eksklusifisme), kesalahan penggunaan agama dikarenakan kesalahan dalam memahami agama dan ajarannya, anggapan agamanya yang paling benar (truth claim), sikap fanatisme yang berlebihan, Agama yang dipolitisasi, kelasahan dalam memahami konsep ajaran sehingga menghasilkan benturan ajaran, kehilangan identitas, fundamentalisme, radikalisme, ekstrimisme, adanya doktrin jihad dan intoleran, minimnya pemahaman terhadap Ideologi pluralism, prasangka.

Implementasi hukum kasih menjadi suatu upaya dalam moderasi dinyatakan dalam tindakan atau perbuatan bukan hanya rencana dan teori saja, tindakan yang dilakukan tidak bisa dibatasi oleh apapun. Kata moderasi berasal dari bahasa Arab yaitu yang berarti moderat, cakupan untuk moderat dalam hal bertindak dan juga dalam segala hal yang baik apakah dalam perkataan, perbuatan, dan juga pikiran. Mohammad Hashim Kamali menyatakan moderasi dapat diartikan berimbang dan adil, sekalipun tidak berarti harus kompromi atau mengimani ajaran agama yang berbeda. Dalam beragama dibutuhkan keadilan dan keseibangan jika tidak beragama hanya akan menjadi angin lalu. ${ }^{42}$ Moderasi berarti suatu komitmen agama untuk mempertimbangkan hak-hak vertical dan juga hak horizontal.

Moderasi dapat dikatakan sebagai jalan tengah di dalam kehidupan masyarakat majemuk yang ada di Indonesia. Dalam hal ini tidak ada sikap saling mempertentangkan namun lebih bersikap toleran. ${ }^{43}$ Sikap inklusif harus dihindari supaya tujuan dari moderasi agama tercapai, menjaga kebersamaan dalam perbedaan, menyatakan rasa saling peduli dan tenggang rasa antar umat yang berbeda yang harus terus dilakukan. Mengimplementasikan hukum kasih dalam kehidupam yang mejemuk ini merupakan tindakan respons atas kasih Allah. Kasih Allah kepada manusia yang menjadi dasar pengimplementasian tersebut menjadikan gereja tidak ragu dalam menyatakan kasih. Jadi sebagai suatu upaya membangun kesadaran akan pluralisme, maka pengimplementasian kasih hukum kasih diimplemtasikan keseluruh aspek kehidupan seperti, ekonomi, politik, social, pendidikan, budaya dan lain-lain.

Dari analisis artikel ini maka didapatkan beberapa temuan yaitu: pertama, agama tidak berfungsi sebagaimana mestinya, kedua tidak terimplementasinya ajaran kasih dengan baik, ketiga konsep hukum kasih yang diimplementasikan dengan akan membangun budaya toleransi dalam moderasi beragama ditengah-tengah kemajemukan yang ada dibangsa Indonesia.

\footnotetext{
${ }^{41}$ John Piper, Apa Yang Yesus Tuntut Dari Dunia (Malang: Literatur SAAT, 2016), 287.

${ }^{42}$ Widodo and Karnawati, "Moderasi Agama Dan Pemahaman Radikalisme Di Indonesia," 2.

${ }^{43}$ Agus Akhmadi, "Moderasi Beragama Dalam Keragaman Indonesia Religious Moderation in Indonesia ' S Diversity," Jurnal Diklat Keagamaan 13, no. 2 (2019): 5.
} 


\section{KESIMPULAN}

Konflik horizontal antar umat beragama yang terjadi menunjukan adanya disfungsi agama. Definisi agama dan ajaran kasih dari masing-masing agama tidak sesuai dengan fakta sebagaimana mestinya. Konsep hukum kasih dengan dasar kasih Allah kepada manusia yang diresponi dengan kasih manusia kepada Allah dan dibuktikan kepada mengasihi sesama seperti mengasihi diri sendiri. Dengan adanya budaya toleransi yang menjadi gaya hidup masyarakat yang majemuk maka konflik dapat dicegah sebelum konflik itu terjadi dan juga dapat diselesaikan atau diperbaiki jika sudah terjadi. Dengan kesadaran toleransi yang dibangun di atas dasar hukum kasih kedamaian antar umat dalam moderasi agama menjadi terwujud. Pada hakekatnya moderasi agama dari perspektif hukum kasih menciptakan kesadaran untuk mewujudkan harmonisasi relasi antar agama, meningkatan rasa kebangsaan dan konstruk positif. Moderasi yang didasari dengan hukum kasih akan memperkuat kesatuan dan persatuan dalam kemajemukan.

\section{REFERENSI}

AAG. Raka Putra. "Cinta Kasih Dalam Perspektif Hindu." Media Hindu. Bekasi, 2016. https://www.mediahindu.org/2016/08/23/cinta-kasih-dalam-perspektifhindu/\#: :text=Adapun yang mendasari cinta kasih,dalam kitab Chandogya Upanisad VI.

Achmad Djatmiko. Agama Dan Kajian Hubungan Internasional. Yogyakarta: ANDI, 2019.

Adon Nasrullah. Agama Dan Konflik Sosial Studi Kerukunan Umat Beragama, Radikalisme Dan Konflik Antarumat Beragama. Bandung: CV.Pustaka Setia, 2015.

Akhmadi, Agus. "MODERASI BERAGAMA DALAM KERAGAMAN INDONESIA RELIGIOUS MODERATION IN INDONESIA'S DIVERSITY." Jurnal Diklat Keagamaan 13, no. 2 (2019). https://bdksurabaya.e-journal.id/bdksurabaya/article/download/82/45. . "Moderasi Beragama Dalam Keragaman Indonesia Religious Moderation in Indonesia' S Diversity." Jurnal Diklat Keagamaan 13, no. 2 (2019): 45-55.

Almasari, Lisa Afsari Putri. "Relevansi Hukum Cinta Kasih Untuk Hidup Beragama Di Indonesia Sekarang Ini," 2019.

Andik Muqoyyidin. "POTRET KONFLI K BERNUANSA AGAMA DI INDONESIA Signifikansi Model Resolusi Berbasis Teologi Transformatif" (n.d.). https://www.researchgate.net/profile/Andik_Muqoyyidin/publication/322050634_links/5a 40e149a6fdcce1970ffe53/POTRET-KONFLIK-BERNUANSA-AGAMA-DI-INDONESIASignifikansi-Model-Resolusi-Berbasis-Teologi-Transformatif.

Andreas A. Yewangoe. Tidak Ada Negara Agama - Satu Nusa, Satu Bangsa. Jakarta: BPK Gunung Mulia, 2009.

BBC Indonesia. "No Title," n.d. https://www.bbc.com/indonesia/indonesia-50471436.

Chaider S. Bamualim (Eds.). Communal Conflicts in Contemporary Indonesia. Jakarta: UIN, KAS, 2002.

Darlis, Andi Muh. Konflik Komunal: Studi Dan Rekonsiliasi Konflik Poso. Yogyakarta: Buku Litera, 2012.

EBA. HOW ALL RELIGIONS ARE FALSE AND HARMFUL: A Scientific Explanation of 7 Major Religions (Judaism, Christianity, Islam, Hinduism, Buddhism, Jainism \& Sikhism). EBA, 2016.

Fahim, M. Sosiologi Agagama Kosenp, Metode Riset, Dan Konflik Sosial. Malang: Madani, 2016.

Gaspersz, Steve Gerardo Christoffel. "Relasi Muslim-Kristen Di Pulau Ambon :," no. 01 (2021). https://www.nusantarainstitute.com/wp-content/uploads/2021/01/NI-Working-Paper-0121-Steve-Gasperz.pdf.

H.M. Ridwan Lubis. Sosiologi Agama Memahami Perkembangan Agama Dalam Interaksi Sosial. Jakarta: Prenadamedia Group, 2015. 
Handayani, Dessy. "Implementasi Hukum Allah Dalam Matius 22:34-40 Bagi Pengembangan Komunitas Kristen" 11 no 1, no. 1 (2020): 49-60. https://ejournal.stapin.ac.id/index.php/pneumatikos/article/view/24.

J.D Doglas. Ensiklopedi Alkitab Masa Kini Jilid 1 A-L. Jakarta: YKBK, 2008.

John Piper. Apa Yang Yesus Tuntut Dari Dunia. Malang: Literatur SAAT, 2012.

Komarudin, Yahya. "KORELASI ANTARA PENGETAHUAN AGAMA ISLAM DAN" 1, no. 1 (2020): 51-73.

Kompas.com. "Kasus Kekerasan Yang Dipicu Masalah Keberagaman Di Indonesia?" Jakarta, 2020.

Lexy J. Moleong. Metodologi Penelitian Kualitatif. Bandung: Remaja Rosdakarya, 2007.

Marbun, Rencan Carisma. "Kasih Dan Kuasa Ditinjau Dari Perspektif Etika Kristen." Jurnal Teologi Cultivation 3, no. 1 (2019): 88-97.

Mihai Stelian Rusu. "Theorising Love in Sociological Thought: Classical Contributions to a Sociology of Love." Journal of Classical Sociology 18, no. 1 (2017): 3-20. https://journals.sagepub.com/doi/10.1177/1468795X17700645.

Mubit, Rizal. "Peran Agama Dalam Multikulturalisme Masyarakat Indonesia." Epistemé: Jurnal Pengembangan Ilmu Keislaman 11, no. 1 (2016): 163-184.

Muryati, Muryati, Gernaida Pakpahan, and Junifrius Gultom. "Sastra Satire Kitab Yunus : Analisis Naratif Prolog Dan Epilog Kitab Yunus" 3, no. 1 (2020): 106-118.

Pakpahan, Gernaida K R. "Analysis of Worring among Lecturers of Indonesian Bethel Theology on Covid-19." Medico-Legal Update 20, no. 4 (2020): 1330-1337.

Petrik Matanasi. "Agama-Agama Nusantara Yang Dipinggirkan." Nusantara Institute (2020): 7. https://www.nusantarainstitute.com/agama-agama-nusantara-yang-dipinggirkan.

Ramli. "Agama Dan Kehidupan Manusia." Jurnal Pendidikan dan Ilmu-ilmu Sosial 7Jurnal Pe, no. 2 (2015): 138-144.

Setyobekti, Andreas Budi, Susanna Kathryn, and Suwondho Sumen. "Implementasi Nilai-Nilai Bhineka Tunggal Ika Dalam Membingkai Keberagaman Pejabat Gereja Bethel Indonesia Di DKI Jakarta." SOTIRIA (Jurnal Theologia dan Pendidikan Agama Kristen) 4, no. 1 (2021): 1-10.

Stephen Prothero. "RELIGIOUS LITERACY What Every American Needs to Know-and Doesn't." Journal of Chemical Information and Modeling 53, no. 9 (2013).

Sumanto AI Qurtuby. "Antara Agama, Manusia, Dan Tuhan." Nusantara Institute (2020): 7. https://www.nusantarainstitute.com/antara-agama-manusia-dan-tuhan/.

Susilo Wibisono \& Muhammad Taufik. "ORIENTASI KEBERAGAMAAN EKSTRINSIK DAN FUNDAMENTALISME AGAMA PADA MAHASISWA MUSLIM: ANALISIS DENGAN MODEL RASCH." Jurnal Psikologi Sosial 15, no. 1 (2017): 1-11. http://journal.ui.ac.id/index.php/jps/article/viewFile/jps.2017.1/3775.

Tatilu, Frits Octavianus. "Hukum Kasih: Landasan Bersama Agama-Agama." Societas Dei: Jurnal Agama dan Masyarakat 4, no. 2 (2018): 219.

Tirto.id. "Ada 32 Gereja Ditutup Sepanjang 5 Tahun, Jokowi Ke Mana?," 2019. https://tirto.id/ada-32-gereja-ditutup-sepanjang-5-tahun-jokowi-ke-mana-dhkD.

Weber, Max. Sosiologi Agama Literatur Utama Dalam Studi Relasi Sosiologi Dan Agama. Yogyakarta: IRCiSoD, 2019.

Widodo, Priyantoro, and Karnawati Karnawati. "Moderasi Agama Dan Pemahaman Radikalisme Di Indonesia." PASCA: Jurnal Teologi dan Pendidikan Agama Kristen 15, no. 2 (2019): 9-14.

Zastrouw Al-Ngatawi. "Agama Tidak Bisa Dilepaskan Dari Tradisi Dan Budaya." Nusantara Institute (2020). https://www.nusantarainstitute.com/agama-tidak-bisa-dilepaskan-daritradisi-dan-budaya/. 